Article

\title{
Social Cost Benefit Analysis of Port Handling Plans for Annex IV waste of MARPOL: A Case Study in Las Palmas Port
}

\author{
Alba Martínez-López ${ }^{1, * \mathbb{C}}$, Alejandro Ruiz-García ${ }^{1}$ and Ivone Pérez ${ }^{2}$ \\ 1 Department of Mechanical Engineering, University of Las Palmas de Gran Canaria, \\ 35017 Las Palmas de Gran Canaria, Spain; alejandro.ruiz@ulpgc.es \\ 2 Department of Applied Economics, University of Las Palmas de Gran Canaria, \\ 35017 Las Palmas de Gran Canaria, Spain; iperez@acciones.ulpgc.es \\ * Correspondence: alba.martinez@ulpgc.es; Tel.: +34-928-34-8090
}

Received: 28 February 2020; Accepted: 16 March 2020; Published: 18 March 2020

check for updates

\begin{abstract}
This paper analyzes the effectiveness of Directive (EU) 2019/883 from the social interest perspective. To achieve this aim, it assesses the performance of the sewage treatment plan (Annex IV of MARPOL) in Las Palmas Port and the accomplishment of the Cost Recovery System. This involves reviewing the mandatory fees for landing the sewage in the port, the sewage treatment costs and the environmental impact of the treated effluent from the vessels (environmental benefits) and addressing technical difficulties in order to meet the normative standard required from the vessels' sewage in the framework of Las Palmas Port. Through a cost-benefit analysis not only the current protocol for the reception and treatment of Annex IV waste in the port is assessed, but also alternative waste treatment plans (sewage routes) are discussed in terms of social interest. The results of the paper show that only when the treated sewage is reused are the costs assumed to implement the directive overtaken by the benefits gained from complying with it. Consequently, the port authorities should address their efforts in this direction, as should the policy makers, who should integrate in the international normative the collaboration of the on-board sewage treatment plants to meet the PPP (Polluter Pays Principle).
\end{abstract}

Keywords: Annex IV of MARPOL; port waste handling plans; sustainable maritime transportation policies and implementation; managing sustainability through collaboration and coordination

\section{Introduction}

The International Maritime Organization (IMO) regulates discharges from spills and waste generated on-board through MARPOL 73/78 (Maritime Pollution 73/78) rules.

Since the 1950s, international organizations have taken action to prevent marine pollution. The International Convention for the Prevention of Pollution of the Sea by Oil (OILPOL 1954) was followed by other interventions on the high seas in cases of oil pollution casualties (INTERVENTION, 1969), prevention of marine pollution by dumping of wastes and other matter (London Convention, 1972) and prevention of pollution from ships (MARPOL, 1973/1978). Later, the 1973 International Convention for the Prevention of Pollution from Ships was modified by the 1978 Protocol (known as MARPOL 73/78).

Thus, it is the International Maritime Organization (IMO) that regulates discharges from spills and waste generated on-board through MARPOL 73/78 (Maritime Pollution 73/78) rules.

To ensure the fulfilment of this international maritime regulation (MARPOL 73/78 Convention-International Convention for the Protection of Pollution from Ships, 1973, as amended by 
the 1978 Protocol) in the EU, Directive 2000/59/EC, as amended by Directive 2015/2087/EC, states that all European Union ports must have adequate waste reception facilities (port waste reception facilities, hereinafter PRF) and perform the withdrawal service without causing unnecessary delays.

EU Directive 2000/59/EC also incorporates a charging system (Cost Recovery System-CRS) based on the "the Polluter Pays Principle" (PPP), so that the charge for this service must be fully self-financed (planning, collection and treatment). In this regard, member states have the autonomy to design their waste treatment plans, their PRFs and the management of their CRS. This heterogeneity in the member countries has generated complaints from users, especially due to the high cost per $\mathrm{m}^{3}$ that must be met by vessels in order to discharge wastes included in Annexes I and IV of MARPOL and the high volumes for treatment. Aware of this situation, the European Maritime Safety Agency (EMSA) has recommended to the European Commission a review of Directive 2000/59/EC to standardize practices and harmonize the interpretation of the rules. In 2016, EMSA published recommendations for the port authorities as a preliminary step to a modification of the directive. In the evaluation carried out by Regulatory Fitness and Performance program (REFIT evaluation; COM 2016(168)) about Directive 2000/59/EC (PRF Directive), a number of 'weak points' were noted. Aside from the aforementioned heterogeneity in the PRF Directive application, the following points can be highlighted:

1. The PRF Directive does not include Annex VI of MARPOL waste in the scope of "ship-generated waste". This means that the waste generated by the "scrubber systems" cannot have reception facilities in the port.

2. Discrepancies between the PRF Directive and land-based waste legislation (at both national and local/municipal level). This enlarges the differences in the handling of waste by port reception facilities and the delivery of waste by port users due to the multiple definitions of different waste types.

3. The costs assumed to implement the directive are not always proportionate to the benefits gained from complying with the directive. This is especially true in ports with scarce resources or additional difficulties, which lead to the development of Waste Reception and Handling Plans (WRHPs) becoming a serious challenge.

4. While the fees must be "fair, non-discriminatory and reflecting actual costs" (PRF Directive; Article 8 (3)) this is not always perceived so, mainly due to the opaque calculations involved.

Recently, Directive (EU) 2019/883 repealed the PRF Directive by addressing some of the gaps identified by the REFIT evaluation, especially related to the whole alignment with the MARPOL; increased harmonization among member states about interpretations of key concepts; the adequacy of the facilities; the obligation of waste delivery to port reception facilities; and the exemption cases, in accordance with the shipping schedule.

While the new directive boosts transparency in the information included in the WRHPs through Article 5 (member states must ensure that the port reception facilities information, the CRS description and the waste management schemes are both publicly available and easily accessible), port users and citizens of port cities nonetheless question whether the costs assumed to meet the directive are adequately compensated by the social benefits gained. This discussion is especially relevant when the treatment of sewage from Annex IV of MARPOL is considered (sanitary wastewater), since it is perceived by the population as being a low polluting residue.

This debate is more intensive in European archipelagos, where the difficulties inherent to insularity (supplies, stockpiles, etc.) are often on top of a high level of port activity (ports with strategic locations). Las Palmas Port provides a case in point. This being one of the main ports in Spain (approximate annual volume of $32,931 \mathrm{~m}^{3}$ of Annex I waters and 48,308.85 $\mathrm{m}^{3}$ of Annex IV waters of MARPOL), the lack of a specific wastewater treatment plant for these waters forces the transfer of bilge waters to wastewater treatment plants located in the Iberian Peninsula in order to comply with the discharge regulations. On the other hand, the treatment plants on the island for treating urban wastewater must 
deal with the treatment of very high volumes of sewage from ships (Annex IV of MARPOL) in relation to the population sizes. Consequently, citizen costs for the service $\left(\operatorname{costs} / \mathrm{m}^{3}\right)$ are high.

Given this reality, this study contributes to deepening knowledge about the implications of Directive (EU) 2019/883 by offering quantitative evidence of the social advantages from its application to the Annex IV residues. In order to address this aim, this paper suggests a method based on a cost-benefit analysis, where the technical feasibility of a number of waste treatment plans (treatment routes) on land, along with alternative on-board treatments for Annex IV wastes are evaluated. The proposed method is applied to the current WRHP and the accomplishment of the Cost Recovery System (CRS) in Las Palmas Port.

Finally, the results of this work are not only useful for port authorities, or waste operators, but also for European policy makers, since it is well known that the regulatory framework is an effective instrument to ensure the Polluter Pays Principle (PPP).

\section{A Brief Literature Review}

While previous research exists regarding ship residue treatment problems from an on-shore perspective, very few publications have provided quantitative evidence about the social advantages of Annex IV sewage treatment (Directive (EU) 2019/883 implementation), by considering its sustainability, implementation costs and the technical limitations of the treatment systems. The few studies there are, however, have produced interesting results about waste reception and handling plans in port, and these findings have been taken into account in this work.

Regarding the application of the PRF Directive and its expected implications, several studies were carried out in different locations and produced innovative findings. Thus, Carpenter et al. [1-3] studied the impact of the directive in the North Sea region. In Greece, with over 3000 islands, the accomplishment of the directive is highly complicated, as oligopoly characteristics were identified in the collection, storage and treatment of port waste in contrast to most European ports [4]. The forthcoming normative was designed as a challenge to boost market competition but it also predictably leads to an increase in the waste volumes of the shore side deliveries [4].

The port handling of waste has been addressed as a specific issue for cruise and passenger ships due to the large amounts of waste generated by them [5-8]. Hence, whereas Peric et al. [9] introduced a model able to predict the Annex IV wastewater volume from cruise activity in the Adriatic Sea, the impact of the recent stringer MARPOL regulation in the Baltic area (the discharge of sewage in Baltic sea for passenger ships has been banned from 2019) was tackled by Wilewska-Bien et al. [7] in terms of capacity of the port reception facilities, and by Vaneeckhaute et al. [8] by analyzing waste management strategies. This last study offers two interesting findings: The need to develop compact and environmentally friendly treatment systems on ships for the sewages and carry out whole assessments of the sewage management (possibility of reuse or biogas). In the same line, Butt [10] concluded, through analysis of the waste generated from cruise ships in Southampton, that there was a need for compulsory investment in new technologies to provide more sustainable systems for on-board waste management. This proposal would minimize the use of waste treatment plant on the shore side. This idea was also reinforced by the results achieved by other authors [2,5,11,12]. Thus, McLaughlin et al. [13] noted that the current treatment systems (Oil Water Separators) for on-board bilge water treatment (Annex I) generally reduced the majority of other potentially harmful pollutants, which are not currently regulated, with the exception of some heavy metals. A different approach to port waste handling was tackled by Lapko et al. [14]. In this case, the authors analyzed the waste collection from yachts and tall ships in a multi-day mass event: A tall ships race with two million tourists taking part. Among other conclusions, the authors noted the importance of early information about the parameters of the ship waste in order to shorten the waste collection time and to appropriately manage the waste.

In light of the above, quantitative studies about the social benefits associated with the application of the directives against the inherent costs of Waste Handling Plans for Annex IV waste were not found. This work contributes to covering this research gap by providing a cost-benefit methodology that 
permits analyzing alternative waste treatment plans (treatment routes in land and on-board treatments systems) through a performance comparison in terms of social benefits. The application of this method to a real-life case: The current scenario of the port of Las Palmas has enabled to quantify the results and provide a reference point in the literature to analyze other contexts where these directives are applicable to sewage (Annex IV).

\section{Sewage Plan Management On-Board}

According to MARPOL 73/78 (IMO, 2017) ship waste can be divided into six annexes that determine the regulation of waste and residue management:

1. Annex I: Regulations for the Prevention of Pollution by Oil.

2. Annex II: Regulations for the Control of Pollution by Noxious Liquid Substances in Bulk.

3. Annex III: Regulations for the Prevention of Pollution by Harmful Substances Carried by Sea in Packaged Form.

4. Annex IV: Regulations for the Prevention of Pollution by Sewage from Ships.

5. Annex V: Regulations for the Prevention of Pollution by Garbage from Ships.

6. Annex VI: Regulations for the Prevention of Air Pollution from Ships.

This paper focuses on the quantitative analysis of Annex IV waste management. This mainly involves sanitary wastewater that can be divided into black water, or sewage, and grey water. The former includes discharge from toilets, urinals, medical rooms and spaces with live animals. On the other hand, grey waters come from baths, showers, washing machines and swimming pools, among other things. The quality of sanitary wastewater is determined by the amount of certain substances and energy contained in the wastewater [9].

The revised Annex IV of MARPOL 73/78 states the treatment requirements for the discharge of these residues on the basis of the distance from the coast (Regulation 11). When the navigation area is 3 nautical miles from the coast, sewage discharge is only permitted when it is fully treated (Advanced Wastewater Treatment System-AWTS) otherwise it must be kept on-board (in wastewater tanks) until it can be discharged in port. In a navigation area between 3 and 12 nautical miles a partially treated discharge of wastewater (comminute and disinfected) is required, through an AWTS or a Marine Sanitation Device-MSD (the latter only treats black waters).

Finally, when the shipping area is further than 12 nautical miles from the coast and the vessel speed is greater than 4 knots, previous treatment of sewage is not compulsory for discharge to be allowed. In any case, the maximum untreated discharge for Annex IV residues (a volume) is limited by Resolution MEPC.157(55) of the Marine Environment Protection Committee (MEPC).

Wastewater treatment plants are certified according to their effluent treatment performance. The Resolutions MEPC.159(55) and MEPC.227(64) identify the effluent standards that must be met to obtain the Certificate of Type Approval by the Administration.

Table 1 shows the required values for the main outputs in land and sea discharges: Biological oxygen demand (BOD), chemical oxygen demand (COD), suspended solids (SS), concentrations of nitrogen $(\mathrm{N})$ and phosphorus $(\mathrm{P})$. It is notable that the maximum values for the most significant outputs coincide with those required by the land normative (Directives 91/271/CEE) for discharging the treated wastewaters into the sea, apart from nitrogenous concentration. Whereas for the land normative the maximum permitted concentration is $10 \mathrm{mg} / \mathrm{L}$ (Directives 91/271/CEE) for the discharge on-board, the limited concentration is $20 \mathrm{mg} / \mathrm{L}$ (MEPC.227(64)).

From these limitations, a first conclusion can be drawn: The main environmental advantage from the land treatment of the Annex IV against the on-board treatment is the $\mathrm{N}$ reduction. The $\mathrm{N}$ concentration required by Directive 91/271/CEE can be achieved by the on-board systems through a specific working range. 
Table 1. Maximum values permitted by the normative for the outputs after sewage treatment for Annex IV discharge.

\begin{tabular}{ccc}
\hline Application & Land & Sea \\
\hline Normative & Directive 91/271/CEE & MEPC.227(64)(Annex 22) \\
\hline COD (mg/L) & 125 & 125 \\
BOD (mg/L) & 25 & 25 \\
SS (mg/L) & 35 & 35 \\
N (mg/L) & 10 & 20 \\
P (mg/L) & 1 & 1 \\
\hline
\end{tabular}

\section{WRHP in Las Palmas Port: The Sewage Plan Management}

Directive 2000/59/EC was incorporated into Spanish Law by Royal Decree 1381/2002 on port facilities for the reception of ship-generated waste and cargo residues. This details the procedure for the reception and treatment of waste in port, which is a service that each port has to offer.

Port reception service for ship generated waste and cargo residues consists of the collection of ship generated waste, its transfer to an authorized treatment facility and, if applicable, its storage, classification and pre-treatment in the area approved by the competent authorities. In order to carry out this service, the owners of the waste reception facilities (waste operators) need a license from the Las Palmas Port Authority (APLP), which is a body that manages Las Palmas Port. In addition, they need an authorization from the competent environmental body and have to demonstrate a commitment to the treatment or disposal of the waste by a final manager. WRHP includes general requirements-aside from the economic-financial, technical and professional solvency to be met by the bidding companies- the technical characteristics and conditions to be met by the waste reception operations and facilities, and the equipment to be provided by the service provider to collaborate in marine pollution control services [15]. Specifically, in order to initiate the service, the captain of a ship heading to the Las Palmas Port has to inform Capitanía Maritima (the Ministry of Public Works and Transport) and APLP of its intention to deliver or keep on-board the waste generated, along with its maximum storage capacity. This notification is mandatory and Capitanía Marítima must verify that there is sufficient storage capacity for the accumulated waste on the ship, in addition to the matter that will be accumulated until it is unloaded.

If there are strong reasons to assume that the intended port of delivery, that is the next port of call, does not have adequate reception facilities or if that port is unknown, Capitanía Maritima has to order the discharge of the waste to avoid the risk of it being dumped at sea on the route between Las Palmas Port and the next port of call. The same procedure applies if the obligation to notify on-board waste is breached and it verifies that the storage conditions are not adequate.

Once the discharge of the ship's waste is confirmed and the vessel is in the port service area, the service can be implemented. The collection can be carried out afloat, by barge or from the side of a ship through a tanker truck or a boat. For safety reasons, this service is exclusively undertaken by barges when the vessel is in the container terminals and is carrying out operations involving the use or movement of cranes along its length, or the length adjacent to the berth of the vessel where the service is provided. Likewise, in support of the ship's pumps and whenever the captain requests it, the waste operator must make available to him or her systems for the pumping-suction of waste in order to complete the transfer in accordance with the required regulations. Once the waste has been removed, the MARPOL certificate is issued to the vessel and the waste is temporarily stored or receives primary treatment.

The waste collected must be treated and disposed of according to the current regulations. When such processes are not carried out by the waste operators' own equipment, they should achieve an agreement with a duly authorized waste manager. In addition, if the final treatment plant is located outside the port, it is necessary to complete the Special Waste Transport Control and Monitoring 
Document, in relation to the applicable regulations of the autonomous community. This might be the case, for example, of Urban Wastewater Treatment Plants (UWTPs).

Figure 1 shows the possible routes for Annex IV waste according to the current WRHP in Las Palmas Port. Currently, the most frequent route is the first (Route 1), while the second (Route 2), is dependent on the Port Wastewater Treatment Plant (PWTP). On the other hand, Route 3 provides a possible new scenario due to the recent PWTP operation.

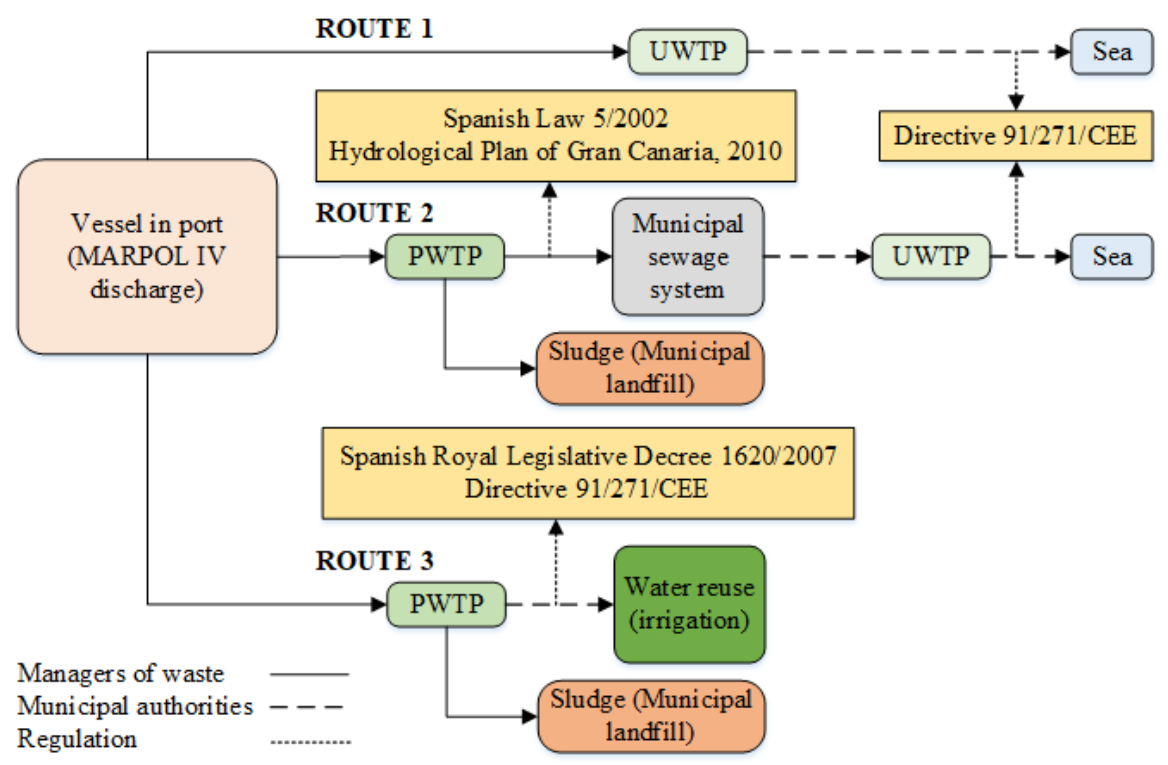

Figure 1. Possible routes for MARPOL IV wastewater according to the current waste handling plan in Las Palmas Port.

In general, this type of service is provided on a regular and continuous basis, it is operational $24 \mathrm{~h}$ a day throughout the year, except in cases of force majeure and a permanent physical presence in port is not required. In the context of the particularities of Annex IV, a low number of operations are being carried out and a low quantity unloaded per operation in Las Palmas Port. Waste operators must also have the human and material resources necessary to provide the service safely, at a specific quality and with continuity and regularity, based on the characteristics of the demand. This is the level that is required for the development of the unitary operations normally expected in port; that is for Annex IV, a service for the collection of waste of $11 \mathrm{~m}^{3}$ to ships at berth.

In order to provide this service, waste operators have to pay various fees, such as a concession fee (Public Domain Occupancy Fee) and an Activity Fee for providing services in the public port domain. In addition, they pay the Vessel Fee, Navigation Aid Fee and Special Use Fee of the transit area.

Ships, for their part, have to pay a fee directly to the waste operator which depends on the volumes loaded. These tariffs have to be public and the APLP has to verify that they do not exceed the maximum tariffs established in the Waste Reception and Handling Plan. Waste operators can define commercial discounts, depending on the volumes of waste delivered each year, among others. These charges include the personnel and material cost involved in the waste collection and, if applicable, storage, sorting and pre-treatment, as well as those relating to transport to an authorized final treatment or disposal facility, and the cost of reception by such plants, and any other expenditure or cost necessary for the provision of the service.

The maximum fees for this service are indicated in the Waste Reception and Handling Plan and are as follows:

1. Reception and treatment:

- $\quad$ By terrestrial means: $63.0 € / \mathrm{m}^{3}$. 
- By barge: $69.5 € / \mathrm{m}^{3}$.

2. Viability

- Minimum turnover per service: $5 \mathrm{~m}^{3}$.

- Pump flow rate less than $5 \mathrm{~m}^{3} / \mathrm{h}$ : A $25 \%$ surcharge on the amount of the tariff per $\mathrm{m}^{3}$ resulting from the quantity that the ship has not discharged in relation to the theoretical volume of discharge, considering the minimum performance of $5 \mathrm{~m}^{3} / \mathrm{h}$, based on:

$$
\mathrm{R}=[(5 \times \mathrm{DRD})-\mathrm{VRD}] \times \mathrm{T} \times 25 \%
$$

where,

R: The total amount of surcharge for the service provided.

T: Fee $\left(71 € / \mathrm{m}^{3}\right.$ in internal port waters or $79.94 € / \mathrm{m}^{3}$ in external port waters).

DRD: Real duration of the download.

VRD: Volume actually discharged from the vessel $\left(\mathrm{m}^{3}\right)$.

3. Operation delays attributable to the vessel

- Delays using terrestrial means: $62.5 € / \mathrm{h}$.

- Delays using barge: $150 € / \mathrm{h}$.

These same fees may be requested by the ship's representative if the delay is due to reasons attributable to the waste operator.

\section{Annexes I and IV Waste (MARPOL) Management after Reception in Las Palmas Port (On-Shore Plan)}

\subsection{Management Regulation}

Post-reception regulation is included in the WRHP in the ports managed by APLP. This regulation establishes that Annex IV waste must be delivered to a treatment plant, without specifying the plant's characteristics. The WRHP mentions that the emission characteristics in waste treatment processes must be in accordance with the current regulation in Spain and in the region. Quality and control requirements established by Directives (EU) 2000/60/CE and 2008/56/CE should be take into consideration when discharges into water bodies are carried out. Since the sewage features from Annex IV are different to urban wastewater, there is an additional difficulty to reach the normative requirements when the Annex IV residues are treated through UWTPs (that are specifically designed to treat urban wastewater).

\subsection{Treatment Problems}

Usually, Annex IV wastewater is transported to UWTPs (see Figure 1) while Annex I waste is transported to the Iberian Peninsula to be treated after being centrifuged (an oil and hydrocarbon separation process). The UWTPs [16] are made to treat wastewater with specific physico-chemical characteristics such as BOD, COD, SS, concentrations of nitrogen $(\mathrm{N})$, phosphorus $(\mathrm{P})$, etc. Normally, the UWTPs undergo a biological treatment, among other processes, to reduce the concentration of BOD, COD, SS, etc., [17] to meet the discharge criteria according to Directives 91/271/CEE and 98/15/CE. Biological treatments in UWTPs involve microorganisms (mainly bacteria), which transform biodegradable organic matter into 'simple products'. Predominantly anaerobic processes are used in UWTPs.

Table 2 shows the maximum required values of outputs to permit the discharge of treated wastewaters to the municipal sewage system in Gran Canaria (see Figure 1). A similar table is required by the Spanish regulation (Law 5/2002) which complements the required values of Table 2. 
Table 2. Limiting values of treated wastewater to be discharged to the sewage system in Gran Canaria.

\begin{tabular}{cc}
\hline Parameter & Limiting Value \\
\hline BOD & $1000 \mathrm{mg} / \mathrm{L}$ \\
pH & $5.5-9.5$ \\
COD & $1600 \mathrm{mg} / \mathrm{L}$ \\
Temperature & $45{ }^{\circ} \mathrm{C}$ \\
Conductivity & $2500 \mu \mathrm{s} / \mathrm{cm}$ \\
SS & $1000 \mathrm{mg} / \mathrm{L}$ \\
Oils and/or fats & $100 \mathrm{mg} / \mathrm{L}$ \\
Mineral oils & $50 \mathrm{mg} / \mathrm{L}$ \\
Aluminum & $2 \mathrm{mg} / \mathrm{L}$ \\
Arsenic & $1 \mathrm{mg} / \mathrm{L}$ \\
Barium & $20 \mathrm{mg} / \mathrm{L}$ \\
Boron & $3 \mathrm{mg} / \mathrm{L}$ \\
Cadmium & $1.5 \mathrm{mg} / \mathrm{L}$ \\
Total chromium & $7.5 \mathrm{mg} / \mathrm{L}$ \\
Iron & $10 \mathrm{mg} / \mathrm{L}$ \\
Manganese & $10 \mathrm{mg} / \mathrm{L}$ \\
Nickel & $10 \mathrm{mg} / \mathrm{L}$ \\
Mercury & $0.1 \mathrm{mg} / \mathrm{L}$ \\
Silver & $0.1 \mathrm{mg} / \mathrm{L}$ \\
Lead & $0.5 \mathrm{mg} / \mathrm{L}$ \\
Selenium & $0.1 \mathrm{mg} / \mathrm{L}$ \\
Tin & $2 \mathrm{mg} / \mathrm{L}$ \\
Zinc & $15 \mathrm{mg} / \mathrm{L}$ \\
Cyanide & $1 \mathrm{mg} / \mathrm{L}$ \\
Chlorides & $600 \mathrm{mg} / \mathrm{L}$ \\
Sulfides & $2 \mathrm{mg} / \mathrm{L}$ \\
Sulfates & $350 \mathrm{mg} / \mathrm{L}$ \\
Fluorides & $1 \mathrm{mg} / \mathrm{L}$ \\
Total phosphorus & $20 \mathrm{mg} / \mathrm{L}$ \\
Ammonia & $50 \mathrm{mg} / \mathrm{L}$ \\
Nitrate & $30 \mathrm{mg} / \mathrm{L}$ \\
Phenols & $1 \mathrm{mg} / \mathrm{L}$ \\
Aldehydes & $1 \mathrm{mg} / \mathrm{L}$ \\
Detergents & $6 \mathrm{mg} / \mathrm{L}$ \\
Pesticides & $3 \mathrm{mg} / \mathrm{L}$ \\
Copper & $3 \mathrm{mg} / \mathrm{L}$ \\
Toxicity & $20 \mathrm{mg} / \mathrm{L}$ \\
Hydrocarbons & $25 \mathrm{mg} / \mathrm{L}$ \\
\hline &
\end{tabular}

In principle, Annex IV waste should have similar characteristics to urban wastewater. However, the utilization of flushing toilets with seawater on-board in order to reduce the freshwater load makes Annex IV waste much more saline than urban wastewater [12]. Table 3 shows a standard composition of Annex IV waste discharge [18-20]. It is important to bear in mind that there is a wide variability in concentrations that are dependent on the sort of ships in port. The salinity range was changed from 5-10 to $1-10 \mathrm{~g} / \mathrm{L}$ and the BOD ranged from $500-800$ to $100-800$ once these values were found in Las Palmas Port.

Table 3 also shows the maximum permitted concentrations for the discharges in the municipal sewage system. These values come from the Hydrological Plan of Gran Canaria, 2010 (see Table 2) and the Spanish Law 5/2002 (see Figure 1). The limiting values for the conductivity were converted to salinity through the relationship: TDS $\mathrm{mg} / \mathrm{L}=\mathrm{CE}(\mu \mathrm{S} / \mathrm{cm})$ when $25^{\circ} \mathrm{C} \times 0.64$ for conductivities $\leq$ $5.000 \mu \mathrm{S} / \mathrm{cm}$. 
Table 3. Composition ranges of Annex IV wastewater and maximum values to discharge in municipal sewage system.

\begin{tabular}{ccc}
\hline Parameter & Range $(\mathbf{m g} / \mathbf{L})$ & Limiting Value \\
\hline COD & $240-1216$ & 1600 \\
BOD $_{5}$ & $100-800$ & 1000 \\
SS & $450-750$ & 1000 \\
N & $111^{*}$ & 60 \\
P & $18.1 *$ & 20 \\
Salinity & $1000-10,000$ & 1600 \\
E. coli & $>100000$ & - \\
(CFU/100 $\mathrm{mL})$ & $*$ Please see $[19]$.
\end{tabular}

Table 3 reveals that the direct discharge of a standard effluent from the vessel to the municipal sewage system would be permitted if the average concentration of $\mathrm{N}$ and the salinity were reduced. While $\mathrm{N}$ reduction up to the required values (see Table 3 ) is not an obstacle for the on-board sewage treatment systems (see Table 1), salinity reduction is not possible with the current on-board technology. The effluents with high salt concentrations exert inhibitory/toxic effects on both aerobic and anaerobic microorganisms during biodegradation processes $[15,16]$. Since the effluents from the municipal sewage systems go to the UWTPs (see Figure 1), the Annex IV waste would affect the correct functioning and separation performance of these plants. Consequently, under current conditions, not only would a discharge of Annex IV to the municipal sewage system be impossible, but also the direct route for Annex IV waste from the vessel to the UWTPs (Route 1 in Figure 1) would not be appropriate from an efficiency standpoint.

The treatment of Annex I waste is a different issue. This oily wastewater has different physico-chemical characteristics in comparison with MARPOL IV waste. Usually, Annex I waste is treated in specific wastewater treatment plants and the discharge criteria to the sewage system has to be in line with the Spanish and regional regulation.

\subsection{Possible On-Shore Solutions to Wastewater Treatment}

The recent building of a specific plant for treating Annex IV waste in port (PWTP) is a promising solution to the technical difficulties highlighted in previous paragraphs. This plant should be able to meet not only the quality criteria of the outputs mentioned in Table 2, but also to treat saline wastewater. In this case, biological treatments are not recommended; consequently, physico-chemical treatment is generally required to remove the organic matter from such effluents. The main technologies that have been researched are coagulation-flocculation, direct flocculation and membrane separation processes [21,22]. The reduction of conductivity or dissolved salt can be achieved by two kind of processes, thermal and membrane. Usually thermal processes are discarded due to their high specific energy consumption in comparison with membrane separation techniques such as nanofiltration (NF) and reverse osmosis (RO) [23]. If the salinity of the wastewater to be treated is close to seawater, seawater reverse osmosis (SWRO) membranes are required as NF and brackish water reverse osmosis (BWRO) membranes are designed to treat brackish water (salt concentration $<10 \mathrm{~g} / \mathrm{L}$ ). The SWRO and BWRO systems require a certain sort of pre-treatment in order to reduce operating problems such as colloidal fouling, etc. Microfiltration cartridge filters $(\sim 5 \mu \mathrm{m})$ and/or ultrafiltration membranes are usually used as a pre-treatment of SWRO and BWRO systems. It has been found that Annex IV waste has salinity in a range of 1 to $10 \mathrm{~g} / \mathrm{L}$ approximately. As can be seen, treating Annex IV waste to meet the criteria for discharge to the sewerage network in Gran Canaria is not a trivial matter.

A physico-chemical treatment and microfiltration of $100 \mu \mathrm{m}$ treatment was tested in Las Palmas Port using Annex IV waste. The COD, BOD and E. coli decreased by 70, 80 and 99.99\%, respectively, while SS and salinity increased by 10 and $800 \mathrm{mg} / \mathrm{L}$ due to coagulant and flocculant dosing. A thinner 
microfiltration stage plus RO treatment would increase the separation efficiency in line with that shown in Table 4.

Table 4. Separation efficiency of microfiltration + reverse osmosis (RO) [24].

\begin{tabular}{cc}
\hline Parameter & Value (\%) \\
\hline COD & 80 \\
BOD $_{5}$ & 83 \\
SS & 100 \\
E. coli (CFU/100 mL) & 100 \\
Salinity & 95 \\
\hline
\end{tabular}

However, it is necessary to take into account that the $\mathrm{RO}$ involves a rejection that is dependent on the initial characteristics of the effluent. According to the initial ranges found for Annex IV (see Table 3), a recovery of $75 \%$ of the total treated effluent by microfiltration $+\mathrm{RO}$ [21] will be assumed. An additional treatment stage would be necessary to treat Annex I waste-an oil/fat separator. It should be noted that treating this type of wastewater can be quite problematic from an operation and maintenance point of view. For example, hydrocarbons have a significant impact on the decrease in RO system performance due to fouling [23]. An RO system in Annex I waste treatment is key for reducing heavy metal concentration and other dissolved pollutants.

\section{Methodology for Cost-Benefit Analysis}

According to a European Commission report (2015) [25], it is possible to evaluate the societal convenience of the application of the Directive (EU) 2019/883 (effectiveness of the directive) through a cost-benefit analysis. From a wider perspective, numerous authors recognize that a cost-benefit analysis is the most suitable method to assess the wastewater management plans [25,26]. However, even though, the costs linked to the implementation of the directive can be clearly established (mainly costs for member states), not all benefits are so easily quantifiable. The market benefits (mainly, for waste operators) can directly be accounted for in monetary terms but the quantification of non-market benefits (the health and environmental benefits) requires specific economic evaluation methods.

In such an analysis the following items must be considered:

1. Costs to member states. The costs for developing and updating (every three years) the WRHPs are carried out by the ports, and finally by the member states. This cost can be calculated by multiplying the average time invested in applying the WRHP per port call by the average wage cost for the public administration (Eurostat).

2. Benefits for human health. This domain includes as essential aspects: Direct medical expenditure for the treatment of illnesses, indirect costs from illness (value of time lost from work, falls in productivity and so on) and suffering related to the illness [27]. Whilst some of the harmful implications on health can be estimated with a market value, the rest are often evaluated through methods based on Willingness to Pay (WTP). In this regard, it is interesting to note the scarce contributions to drinking water quality and the effect of improving it from WTP methods.

3. Environmental benefits. The environmental benefits in avoiding sewage discharges to the sea are evident; however, their quantification is complicated. The 'stated preference methods' are the most habitual for assessing environmental impacts [27]. These are based on survey techniques for individuals (WTP surveys for example) regarding a particular environmental good where people directly state their intentions (Contingent Valuation-CV). In turn, the 'revealed preference methods' (travel cost and hedonic methods) indirectly 'reveal' economic values from behaviors. However, in recent years a 'shadow price' method has become more influential in this kind of analysis [27]. The method assumes as a productive process the sewage treatment where harmful outputs (BOD, COD, SS, etc.) are processed through inputs (energy, personnel hours, etc.). The establishment of the shadow prices for the outputs allows the environmental damage 
to be evaluated. This method is widely used for air pollution analysis, and industrial waste evaluations, among other applications. The European Commission's report (2015) [25] established a method based on a comparable indicator for the estimation of the environmental benefits; this is a calculation of the costs for cleaning coastal sewage (costs avoided by the discharges) by taking into account the increase of the sewage volume in port (Annex IV of MARPOL) due to the application of Directive (EU) 2019/883.

4. Benefits for productive activities. The directive application involves incentives for discharges in port reception facilities. Consequently, the European Commission's report [25] identified as the main beneficiaries: The waste operators who have increased their service demands and therefore additional benefits are expected for them. However, the cost recovery system sometimes covers a part of the waste delivery costs. Hence, it is complicated to calculate in advance an increase in profitability for these companies. Nevertheless, other productive activities can take advantage of the treatment of Annex IV waste. This includes, among others, agricultural productivity (safe wastewater irrigation), the maintenance of safe captures of fish and shellfish and the conservation of the atmosphere for recreational services (in the tourism sector).

5. Costs by the treatment systems. Whilst these costs are closely associated with the process route for the sewage handling plan (see Figure 1), they are mainly supported by waste operators and by public wastewater treatment plants (local plants). Thus, the reduction process of undesirable outputs is carried out through the following necessary inputs (among others): Energy, personnel staff, reagents and maintenance [27]. All of these carry with them associated costs.

The method proposed is based on the proportion of the costs incurred, the benefits achieved and the port fees charged for it. In other words, the port fees (Annex IV) for meeting Directive (EU) 2019/883 should be sufficient to cover at least the treatment costs and the administrative costs from the directive application. Since, according the directive, the SCR must be not only a fully self-financed charge but also a fair, non-discriminatory charging system by reflecting actual costs, an imbalance between costs, benefits and charges directly affects the effectiveness of the CRS and the directive. Consequently, this balance should be carefully analyzed.

\subsection{Application to Las Palmas Port}

In this section, the methodology shown in the previous paragraphs is applied to the particular case of Las Palmas Port. In such a way, through a cost-benefit analysis, the social advantages and drawbacks from Annex IV sewage treatment will be revealed by considering the current regulatory framework. As one of the consequences, the suitability of the CRS to the management of the Annex IV sewage in Las Palmas Port will be evaluated.

\subsubsection{Inputs from Las Palmas Port}

This empirical application considers information for the year 2018. Table 5 collects general information about the port activity during 2018; it shows the assumed performance for the treatment plants involved in the possible routes for sewage handling in Las Palmas Port (see Figure 1).

Table 5. General information about port activity in Las Palmas Port.

\begin{tabular}{cc}
\hline Annex IV (2018) & Values \\
\hline Yearly Volume $\left(\mathrm{m}^{3}\right)$ & $48,308.85$ \\
Annual calls & 10,050 \\
Fees $\left(€ / \mathrm{m}^{3}\right)$ & 63 \\
\hline (Source: Las Palmas Port authority).
\end{tabular}


The initial values shown in Table 6 were taken from Table 3, and in turn the PWTP values were provided by applying information from Table 4. Finally, the output values shown from the UWTP are those limits identified in Directive 91/271/EEC.

Table 6. Estimated values for the outputs after sewage treatment from a standard test in an Annex IV discharge.

\begin{tabular}{cccc}
\hline Parameter $(\mathbf{m g} / \mathbf{L})$ & Initial Values (Standard Discharge) & Outputs from PWTP & Outputs from UWTP \\
\hline COD & 728 & 43.68 & 125 \\
BOD $_{5}$ & 400 & 13.6 & 25 \\
SS & 600 & 0 & 35 \\
$N$ & 111 & 19.98 & 10 \\
P & 18.1 & 1.267 & 1 \\
Salinity & 5000 & 290 & - \\
\hline
\end{tabular}

PWTP: Port Waste Treatment Plant; UWTP: Urban Waste Treatment Plant.

According to Figure 1, three different routes are possible for the handling plan of the sewage (Annex IV waste) in Las Palmas Port: Route 1 (where only UWTP is involved), Route 2 (in which the sewage is treated by two plants: PWTP and UWTP) and Route 3 (only PWTP treatment is necessary). This leaves three different scenarios with different costs and benefits. In this domain, it is interesting to bear in mind that the PWTP treated water meets the requirements for its reuse in agrarian activities (irrigation of crops, according to Spanish Regulation-the Royal Legislative Decree 1620/2007); this destination for the effluent corresponds to Route 3 (see Figure 1).

\subsubsection{Costs Associated with Annex IV Management (Costs to Member States)}

Only the costs for the port management of the Annex IV sewage have been considered in this regard. While the administrative burden is shared with other stakeholders: Capitanía Maritima (the Ministry of Public Works and Transport) for inspection, and the port users (vessel operators) for advance notifications. Due to the lack of accurate information, only the port costs related to this aim have been assumed as "costs to member states".

According to the APLP, the Department of Sustainability, Safety and Security from Las Palmas Port invested $60 \%$ of their time in 2018 into managing the MARPOL residues, and specifically 10\% annually was necessary for Annex IV management. This involves advance notifications and the developing and updating of WRH plans (and exceptions). Taking into account the 1736 working hours in $2018,173.6 \mathrm{~h}$ were dedicated to sewage management in Las Palmas Port, regardless of the route followed on-shore by the Annex IV discharges (see Figure 1). Assuming an average hourly wage cost for administrative tasks in 2018 of $14.40 € / \mathrm{h}$ (II Collective agreement for workers of State Ports and Port authorities of Spain; BOE N9, 11 January, 2006) the cost results can be seen in Table 7.

Table 7. Costs associated with Annex IV management in Las Palmas Port (2018).

\begin{tabular}{cc}
\hline Item & Cost \\
\hline Average wage costs $(€ / \mathrm{h})$ & 14.4 \\
Administrative burdens (yearly time in hours) & 173.6 \\
Yearly costs for MARPOL IV management & 2499.84 \\
Cost per call $(€ /$ call $)$ & 0.25 \\
Cost per volume $\left(€ / \mathrm{m}^{3}\right)$ & 0.06 \\
\hline
\end{tabular}

\subsubsection{Environmental Benefits}

The shadow prices method was assumed to calculate the environmental benefits from the application of treatment systems for the sewage from Annex IV of MARPOL. In such a way, the environmental benefits are assessed through shadow prices associated with the undesirable 
outputs of the sewage [27]. While the treated outputs that are involved in the water pollution are numerous, this study has focused on four (see Table 1): Nitrogen (N), phosphorus (P), SS and organic matter. The latter is measured as BOD and COD.

In Table 8, the shadow prices of the previous pollutants are shown for the year 2018 in Spain (the initial values published by Hernández-Sancho et al., 2010 [27], were updated through the Consumer Price Index (CPI) for 2018 from 2004). These values represent the environmental benefit (environmental damage avoided) from removing these pollutants in the discharges.

Table 8. Shadow prices for the undesirable outputs in 2018 [27], updated CPI Spain 2018.

\begin{tabular}{cccc}
\hline Destination of Effluent & & Sea & Wetlands/Irrigation \\
\hline Reference price for the treated water $\left(€ / \mathrm{m}^{3}\right)$ & & 0.128 & 1.150 \\
& $\mathrm{~N}$ & -5.902 & -83.337 \\
& $\mathrm{P}$ & -9.627 & -132.176 \\
Shadow prices for undesirable outputs $(€ / \mathrm{kg})$ & $\mathrm{SS}$ & -0.001 & -0.013 \\
& BOD & -0.006 & -0.150 \\
& COD & -0.013 & -0.156 \\
\hline
\end{tabular}

The shadow prices along with the reference prices are highly dependent on the destination effluent. Routes 1 and 2 (see Figure 1) discharge their effluents into the sea. While the final destination of the effluents is the same on these routes, the treatment process is different and also the quality of the effluent. Thus, Route 1 treatment (see Figure 1) is only suitable for discharges into the sea. Route 3 allows for the possibility of reusing the water through a unique treatment plant (PWTP). For that reason, two possible destinations are considered for the discharges from the routes: The sea and irrigation (wetlands). Additionally, it is assumed that only $75 \%$ of the initial effluent [28] will be recovered after the OR treatment in the PWTP (Routes 2 and 3) and the rejection is sent to the municipal landfill (see Figure 1).

Taking into account the three possible scenarios for the analysis (see Figure 1), Table 9 shows the expected final values for the harmful outputs by taking into account the route followed for the sewage treatment. Additionally, this table shows the treatment plant that is responsible for reaching the maximum expected values in every case.

Table 9. Maximum values reached for the possible routes in the sewage treatment in Las Palmas Port and responsible plants.

\begin{tabular}{cccccc}
\hline $\mathbf{m g} / \mathbf{L}$ & Route $\mathbf{1}$ & Route $\mathbf{2}$ & Route $\mathbf{3}$ & PWTP (Routes) & UWTP (Routes) \\
\hline COD & 125 & 43.68 & 43.68 & 2 and 3 & 1 \\
BOD $_{5}$ & 25 & 13.6 & 13.6 & 2 and 3 & 1 \\
SS & 35 & 0 & 0 & 2 and 3 & 1 \\
N & 10 & 10 & 19.98 & 3 & 1 and 2 \\
P & 1 & 1 & 1.267 & 3 & 1 and 2 \\
Salinity & - & 290 & 290 & 2 and 3 & - \\
\hline
\end{tabular}

Despite the fact that selective treatment in the urban waste treatment plant (UWTP) for specific pollutants is not possible, this plant would only be necessary in Route 2 (discharge into the sea) to meet the required values for N and P concentration from the delivery of the PWTP (see Tables 1 and 6). The remaining pollutants are significantly reduced by PWTP in Route 2 in comparison to the final values reached by Route 1 (where only UWTP is involved-see Table 9).

Table 10 collects the environmental benefits calculated for the possible routes and the effluent destinations. While the overall results offer similar advantages through Routes 1 and 2, where the sea is the final destination of the effluent, a significant improvement in environmental benefits is found through Route 3, where the effluent is reused (see Figure 1). 
Table 10. Environmental benefits obtained from the treatment of the Annex IV waste in Las Palmas Port (2018).

\begin{tabular}{cccc}
\hline Parameter (€/year) & Route 1 (Sea) & Route 2 (Sea) & Route3 (Wetland/Irrigation) \\
\hline COD & 333.75 & 284.07 & 3465.67 \\
BOD & 103.77 & 80.20 & 1876.68 \\
SS & 31.27 & 24.91 & 249.07 \\
N & $25,815.63$ & $19,361.72$ & $246,384.36$ \\
P & 7129.70 & 5347.28 & $72,268.93$ \\
Overall $(€)$ & $33,414.14$ & $25,098.18$ & $324,244.72$ \\
$\left(€ / \mathrm{m}^{3}\right)$ & 0.771 & 0.579 & 7.487 \\
\hline
\end{tabular}

The role of treated water as an economic resource for irrigation in agriculture is especially significant in the Canary Islands, due to the lack of rivers and sweet water lakes. This leads to substantial environmental benefits through Route 3 (see Table 10) with a high reference price for this treated water (see Table 8) in comparison to that poured into the sea.

\subsubsection{Human Health Benefits}

In the context of developing countries (especially for Sub-Saharan Africa), a number of studies have been published on the economic evaluation of the effects on human health by wastewater treatments. However, the benefits identified in this research are not applicable to the current case study due to the different economic and societal frameworks. For that reason, despite the existence of the human health benefits in sewage treatment, this study assumes that these might be negligible in the application case.

\subsubsection{Benefits from Productive Activities (Industrial Benefits)}

As said before, the industrial benefits from the directive application for waste operators are evident; however, the estimation of this profit is complicated. Thus, this possible advantage can be estimated through the cost-benefit analysis. Aside from waste operators in port (Annex IV residues management), the agriculture sector, the fishing sector and tourism (with a high impact on the economy of the Canary Archipelago) will be directly affected by the sewage treatments and the possibilities of its reuse.

While the final destination of the effluent is not an unquestionable driver of the benefited sector, it is a reliable indicator. The treated waters, with the sea as a final destination (Routes 1 and 2, see Figure 1), obviously impact the fishing and recreational sector, whereas the treated waters for irrigation uses (wetland destination in Route 3) potentially benefit agriculture and tourism. These productive benefits have been quantified through reference prices. The reference prices show the willingness to pay for initiatives related to maintaining or improving water quality in this domain (Spanish Authorities [27]).

\subsubsection{Costs by the Treatment Systems}

According to the possible routes, the treatment plants involved in the processes are different and as a consequence of this the treatment costs are also different (see Figure 1). Table 11 collects the costs associated with the plants provided by the owners (PWTP) and the public tariffs charged by the urban plant (UWTP) to the waste operators. In this latter case, the UWTP manager in Las Palmas Port has provided estimated costs for the operation, of $1 € / \mathrm{m}^{3}$. Despite high dependence of the wastewater treatment costs on the treated volume, and the reduction of eutrophication, the operation costs for these plants (UWTP) found in the literature are between 0.2 and $0.6 € / \mathrm{m}^{3}$ (2018 values; [29]) with an average value for the UWTP plants in Spain of $0.3 € / \mathrm{m}^{3}$ [30]. In any case, these costs are very far from the required UWTP tariffs (see Table 11) for waste operators. Therefore, a significant margin between the real cost and the tariffs seems to exist. This involves significant market benefits for the UWTP by considering its operating and construction costs [16]. 
Table 11. Costs of the treatment systems of the sewage Annex IV in Las Palmas Port (2018).

\begin{tabular}{cccc}
\hline & Route 1 (Sea) & Route 2 (Sea) & Route 3 (Wetland/Irrigation) \\
\hline PWTP $\left(€ / \mathrm{m}^{3}\right)$ & - & 2.8 & 2.8 \\
UWTP $\left(€ / \mathrm{m}^{3}\right)$ & 16.5 & 16.5 & - \\
Municipal landfill & & 3.6 & 3.6 \\
$\quad$ Sludge) & 16.5 & $18.77 *$ & 6.4 \\
Total costs $\left(€ / \mathrm{m}^{3}\right)$ & $714,596.02$ & $813,123.66$ & $277,176.64$ \\
Yearly costs $(€)$ &
\end{tabular}

* Average cost by assuming 100\% effluent in PWTP and 75\% effluent in UWTP.

\section{Results}

The costs and benefits that could be quantified for the application case of Las Palmas Port, according to the above sections, are shown in Table 12. Despite the existing limitations to estimating the costs and benefits, some insights can be drawn from the analysis.

Table 12. Cost-benefit analysis for 2018 of Annex IV waste management in Las Palmas Port.

\begin{tabular}{ccccccc}
\hline & \multicolumn{2}{c}{ Route 1 (Sea) } & \multicolumn{2}{c}{ Route 2 (Sea) } & \multicolumn{2}{c}{ Route 3 (Wetland/Irrigation) } \\
\hline & Yearly Costs $(€)$ & $€ / \mathrm{m}^{3}$ & Yearly Costs $(€)$ & $€ / \mathrm{m}^{3}$ & Yearly Costs $(€)$ & $€ / \mathrm{m}^{3}$ \\
CMS & 2499.84 & 0.06 & 2499.84 & 0.06 & 2499.84 & 0.06 \\
CTS & $714,596.03$ & 16.5 & $813,123.66$ & 18.8 & $277,176.64$ & 6.40 \\
Total Costs & $717,095.87$ & 16.5 & $815,623.50$ & 18.8 & $279,676.48$ & 6.46 \\
EB & $33,414.14$ & 0.77 & $25,098.18$ & 0.58 & $324,244.72$ & 7.49 \\
IB & 5534.87 & 0.13 & 4151.15 & 0.10 & $37,360.37$ & 0.86 \\
TotalBenefits & $38,949.01$ & 0.90 & $29,249.34$ & 0.68 & $361,605.10$ & 8.35 \\
Port-Users & $2,728,457.5$ & 63.0 & $2,728,457.5$ & 63.0 & $2,728,457.5$ & 63.0 \\
ExtraBenefits & $2,011,361.7$ & 46.4 & $1,912,834.0$ & 44.2 & $2.448 .781,1$ & 56,54 \\
\hline
\end{tabular}

CMS: Costs to Member State; CTS: Costs by Treatment Systems; EB: Environmental Benefits; IB: Industrial Benefits.

Table 12 indicates that the total costs are higher than the total benefits when the final destination of the effluent is the sea (Routes 1 and 2) and the incomes from the port users are not considered. In spite of the fact that not all benefits have been quantified (e.g., human health benefits), only Route 3 provides greater benefits than costs. However, when the incomes associated with the port fees for Annex IV waste management are considered (port users in Table 12), significant extra benefits arise as a result of the difference between the total costs and the income from port fees (port-users).

It is reasonable to assume that these extra benefits correspond to additional benefits for industry. Due to the fact that the fees are directly charged by the waste operators for Annex IV management, the main beneficiaries are those stakeholders with an estimated margin of between 44 and $56.5 € / \mathrm{m}^{3}$ (see Table 12). Nonetheless, these margins do not necessarily involve large profits, since a number of items relating to their activity were not taken into account: Capital costs (PWTP in Routes 2 and 3; see Figure 1), storage and transportation costs (for all routes), maintenance costs, etc. Likewise, the estimated difference between the public tariffs charged by the UWTP and the real costs provides margins of up to $10 € / \mathrm{m}^{3}$.

While the lack of complete information about some costs and benefits advises prudence with the interpretation of the results obtained, due to the wide difference between costs and benefits, we can affirm that only Route 3, which is able to reuse the treated water, offers social benefits that outweigh the costs. Through Route 3, social benefits increase to $8.3 € / \mathrm{m}^{3}$, while the costs incurred are the lowest $\left(6.46 € / \mathrm{m}^{3}\right)$. Unlike Route 3, the other routes do not offer higher benefits than costs. Nevertheless, Route 2, against Route 1, provides an additional advantage because it avoids significant technical difficulties (deficiencies in the treatment process) in UWTP associated with the high salinity of Annex IV residues. 
The costs invested in the most frequent Annex IV waste management in Las Palmas Port (Route 1) have significantly exceeded the benefits for citizens. In this regard, the large difference between the estimated costs for the treatment process in the UWTP and the tariffs charged to the waste operators is especially noteworthy. However, even if a reduction in these tariffs was applied, they would not be able to result in benefits from Routes 1 and 2 surpassing the costs. This finding is in line with a number of statements from member states' port authorities that affirmed that the benefits from MARPOL management are not always proportional to the costs incurred for developing, updating and applying the WRH plans (COM 2016(168)).

Paying attention to the suitability of the CRS for Annex IV waste, port users costs due to the fees have proven to be very significant. This income not only broadly covers the costs assumed for Annex IV waste management, but also provides extra benefits for the market. Despite the fact that the waste operator has to pay the tariff to the UWTP, and a number of costs involved in its activity were not assessed, the estimated margin has proved to be very high $\left(40-56.5 € / \mathrm{m}^{3}\right.$ over a port fee of $\left.63 € / \mathrm{m}^{3}\right)$. Again, the quantitative results have confirmed the port user's perception (COM 2016(168)): The current fees are not proportional to the current costs (there is a lack of accuracy in the fee calculation).

\section{Analysis and Discussion about the On-Board Alternatives}

Paying attention to the range values of the parameters for an Annex IV test in Las Palmas Port (see Table 3) and the normative requirements for a direct discharge to the municipal sewage system (Spanish Law 5/2002 and [31]), there exists the possibility of finding discharges with concentrations that are able to meet the normative without previous treatment (see, Table 3). This scenario would require controlling discharge concentrations from the vessels and it would permit large savings in transportations. Once in the municipal sewage system, the effluent would follow Route 1 (see Figure 1). Unfortunately, a real time control of Annex IV waste is not technically possible in port. Therefore, this option is currently unfeasible.

The high costs for on-shore treatments in relation to the social benefits along with the proximity of the normative requirements for the effluent discharges to the sea from the vessel and land (see Table 1) lead to one possibility: The on-board treatment of Annex IV waste. This proposal was already suggested in the past by other authors [2,4], who affirmed that the development and improvement of on-board technologies are the most sustainable options for the management of waste generated by the vessels.

As stated above, the output values for the treated sewage by current on-board plants (certified plants according to MEPC.227(64)) are able to be accomplished with the land required values (Directives 91/271/CEE) for discharges at sea, excepting the N concentration. However, this latter exception might be achieved through current on-board plants. In such a case, the on-board treated sewage could be directly discharged to the sea from the vessel. When port regulations do not allow discharges during the berthing time (Article 62 of Royal Legislative Decree 2/2011), the waste operator should transport the sewage to an urban wastewater pumping station to be discharged. In such a case, although the expected benefits remain the same as those of the Route 1 (see Figure 1 and Table 12), the total costs would be significantly reduced, but in neither case would the benefits cover the costs.

Another scenario would be assuming an on-board RO process. In such a case, not only would the $\mathrm{N}$ concentration meet the required values to discharge into the sea (Directive 91/271/CEE), but also the salinity of the effluent would be reduced by making possible any further reutilization.

Table 13 shows the comparison, in terms of cost-benefit analysis, between this on-board alternative and Route 3, where the reuse of the treated sewage was also considered. The costs of the on-board treatment systems were estimated by assuming the current capacities of the sewage plants of the Ro-Pax fleet $(2 \times$ harmworthy ST40), which regularly operate in Las Palmas Port, but adding RO technology $\left(0.55 € / \mathrm{m}^{3}\right)[29,30,32]$. This fleet represents $42.6 \%$ (2009 data) of the total calls to the Las Palmas Port. Additionally, the management cost of $\mathrm{RO}$ residues (the osmosis rejection, which represents $25 \%$ of the total sewage) by the waste operators is also included $\left(16.5 € / \mathrm{m}^{3}\right.$; see Table 11 and Figure 1$)$. 
Table 13. Comparison of cost-benefit analysis for Annex IV waste management through Route 3 and on-board RO process in Las Palmas Port (2018).

\begin{tabular}{ccccc}
\hline & \multicolumn{2}{c}{ Route 3 (Wetland/Irrigation) } & \multicolumn{2}{c}{ On-Board (RO-Process) (Reuse) } \\
\hline & Yearly Costs $(€)$ & $€ / \mathrm{m}^{3}$ & Yearly Costs $(€)$ & $€ / \mathrm{m}^{3}$ \\
CMS & 2499.84 & 0.06 & 2499.84 & 0.06 \\
CTS & $277,176.64$ & 6.40 & $202,468.87$ & 4.68 \\
Total Costs & $279,676.48$ & 6.46 & $204,968.71$ & 4.73 \\
EB & $324,244.72$ & 7.49 & $324,244.72$ & 7.49 \\
IB & $37,360.37$ & 0.86 & $83,023.07$ & 1.92 \\
Total Benefits & $361,605.10$ & 8.35 & $407,267.79$ & 9.40 \\
Port-users & $2,728,457.5$ & 63.00 & $682,114.39$ & 63.00 \\
Extra Benefits & $2.448 .781,1$ & 56.54 & $477.145,67$ & 11.02
\end{tabular}

CMS: Costs to Member State; CTS: Costs by Treatment Systems; EB: Environmental Benefits; IB: Industrial Benefits.

While the environmental benefits (EB) are the same as those achieved by Route 3 (see Figure 1), the industrial benefits (IB) are higher (see Table 13). This is so because the most probable reuse of this water is not the wetland (like in Route 3), rather it is for flushing toilets to reduce freshwater use on the vessel. This involves a higher value for this treated water (reference price $1.92 € / \mathrm{m}^{3}$; see Table 8 [30]).

Thus, due to the higher benefits and the lower costs provided by the on-board RO process, this option has proven to be the most interesting among the evaluated alternatives (see Tables 12 and 13).

\section{Conclusions and Policy Implications}

From the results of this work, a number of findings can be drawn. Firstly, only when the final destination of the treated sewage in the WRHP is reused do the social benefits exceed the costs incurred in Annex IV treatments. In contrast, the most frequent routes involve UWTP activity, the treatment processes of which are designed for sewages without salt concentrations. Consequently, aside from the under-sizing of the urban plants, significant inefficiencies arise in the treatment process of Annex IV residues. In addition, the on-board collaboration for the sewage treatment in port has proven to be a promising solution. If the Annex IV waste is previously treated by the sewage treatment systems of the vessels, the costs are significantly reduced. This reality offers the possibility of a green charge in port. Likewise, the most sustainable solution was found when the sewage was treated by an on-board RO process. In this case, not only could the treated sewage be used by the vessel's own services, but also it would reduce the Annex IV volume discharged in the port by the vessel by up to $25 \%$. This solution, aside from optimizing the social benefits, contributes to solving additional problems noted by previous studies: The reduction of the residue volumes to be handled in land processes [4-8] through on-board collaboration [2-4], the rationalization of the capacity reception facilities in port [7] and the optimization of waste management strategies [8,33]. Finally, for the application case, a relevant mismatch was founded between the port tariffs for Annex IV management and the incurred costs.

In light of the foregoing, we conclude that there is an evident need for port and local authorities to jointly review the current WRHP by considering its performance from a social interest perspective in Las Palmas Port. In parallel, a greater effort should be made by local, national and international policy makers to co-ordinate the definition of rules from a wider perspective. Thus, as mentioned above, slight differences between land and sea legislation relating to required parameters to discharge to sea can involve high costs for vessels, port operators and citizens. Finally, as it is well known that the regulatory framework is an effective instrument to ensure the PPP and improve technological development for sustainability, policy makers should promote, through regulations, the installation of $\mathrm{RO}$ sewage treatment plants in the vessels to address this issue.

Author Contributions: Conceptualization, A.M.-L. and A.R.-G.; methodology, A.M.-L. and I.P.; formal analysis, A.M.-L.; investigation, A.M.-L., A.R.-G. and I.P.; resources, A.M.-L., A.R.-G. and I.P.; writing-original draft preparation, A.M.-L.; writing-review and editing, A.M.-L., A.R.-G. and I.P.; supervision, A.M.-L., A.R.-G. and I.P.; All authors have read and agreed to the published version of the manuscript. 
Funding: This research received no external funding.

Acknowledgments: Many thanks to the anonymous reviewers for the time dedicated to improve this paper. This paper was supported by the 'Cátedra Marítimo-Portuaria'.

Conflicts of Interest: The authors declare no conflict of interest.

\section{References}

1. Carpenter, A.; Macgill, S. Charging for Port Reception Facilities in North Sea Ports: Putting Theory into Practice. Mar. Pollut. Bull. 2001, 42, 257-266. [CrossRef]

2. Carpenter, A.; Macgill, S.M. The EU directive on port reception facilities for ship-generated waste and cargo residues: Current availability of facilities in the North Sea. Mar. Pollut. Bull. 2003, 46, 21-32. [CrossRef]

3. Carpenter, A.; Macgill, S.M. The EU Directive on port reception facilities for ship-generated waste and cargo residues: The results of a second survey on the provision and uptake of facilities in North Sea ports. Mar. Pollut. Bull. 2005, 50, 1541-1547. [CrossRef] [PubMed]

4. Giantsi, T.; Tsioupli, S.; Flegkas, K.; Koufos, P.; Angelopoulos, J. Collection and Handling of Ship Waste and Cargo Residues in Greece: Present and Future. In Proceedings of the International Conference Protection and Res-Toration of the Environment XIV, Thessaloniki, Greece, 3-6 July 2018.

5. Piazzese, D.; Corsino, S.F.; Torregrossa, M.; Bongiorno, D.; Indelicato, S.; Viviani, G. Effect of a co-substrate supply in a MBR treating shipboard slop: Analysis of hydrocarbon removal, biomass activity and membrane fouling tendency. Biochem. Eng. J. 2018, 140, 178-188. [CrossRef]

6. Tomei, M.C.; Mosca Angelucci, D.; Stazi, V.; Daugulis, A.J. On the applicability of a hybrid bioreactor operated with polymeric tubing for the biological treatment of saline wastewater. Sci. Total. Environ. 2017, 599-600, 1056-1063. [CrossRef] [PubMed]

7. Wilewska-Bien, M.; Anderberg, S. Reception of sewage in the Baltic Sea-The port's role in the sustainable management of ship wastes. Mar. Policy 2018, 93, 207-213. [CrossRef]

8. Vaneeckhaute, C.; Fazli, A. Management of ship-generated food waste and sewage on the Baltic Sea: A review. Waste Manag. 2020, 102, 12-20. [CrossRef] [PubMed]

9. Perić, T.; Komadina, P.; Račić, N. Wastewater pollution from cruise ships in the Adriatic Sea. Promet-Traffic Transp. 2016, 28, 425-433. [CrossRef]

10. Butt, N. The impact of cruise ship generated waste on home ports and ports of call: A study of Southampton. Mar. Policy 2007, 31, 591-598. [CrossRef]

11. Campo, R.; Giustra, G.M.; De Marchis, M.; Freni, G.; Di Bella, G. Characterization and Treatment Proposals of Shipboard Slop Wastewater Contaminated by Hydrocarbons. Water 2017, 9, 581. [CrossRef]

12. Jiang, L.; Chen, X.; Qin, M.; Cheng, S.; Wang, Y.; Zhou, W. On-board saline black water treatment by bioaugmentation original marine bacteria with Pseudoalteromonas sp. SCSE709-6 and the associated microbial community. Bioresour. Technol. 2019, 273, 496-505. [CrossRef] [PubMed]

13. McLaughlin, C.; Falatko, D.; Danesi, R.; Albert, R. Characterizing shipboard bilgewater effluent before and after treatment. Environ. Sci. Pollut. Res. 2014, 21, 5637-5652. [CrossRef] [PubMed]

14. Łapko, A.; Strulak-Wójcikiewicz, R.; Landowski, M.; Wieczorek, R. Management of Waste Collection from Yachts and Tall Ships from the Perspective of Sustainable Water Tourism. Sustainability 2018, 11, 121. [CrossRef]

15. Las Palmas Port Authority. Pliego de Prescripciones Particulares del Servicio Portuario de Recepción de Desechos Generados por Buques en Los Puertos Gestionados por la Autoridad Portuaria de Las Palmas (BOE-A-2015-7550); Ministry of Development Madrid: Madrid, Spain, 2015.

16. Acampa, G.; Giustra, M.G.; Parisi, C.M. Water Treatment Emergency: Cost Evaluation Tools. Sustainability 2019, 11, 2609. [CrossRef]

17. Christensen, M.L.; Keiding, K.; Nielsen, P.H.; Jørgensen, M.K. Dewatering in biological wastewater treatment: A review. Water Res. 2015, 82, 14-24. [CrossRef] [PubMed]

18. Zhu, L.; He, H.; Wang, C. COD removal efficiency and mechanism of HMBR in high volumetric loading for ship domestic sewage treatment. Water Sci. Technol. 2016, 74, 1509-1517. [CrossRef]

19. Chen, R.; Shi, J.; Wang, Z. Method Study on Establishing of Ship Sewage Pollutants Discharging Inventory Based on \{AIS\}. IOP Conf. Ser. Earth Environ. Sci. 2019, 237, 22018. [CrossRef] 
20. Cai, Y.; Li, X.; Zaidi, A.A.; Shi, Y.; Zhang, K.; Feng, R.; Lin, A.; Liu, C. Effect of hydraulic retention time on pollutants removal from real ship sewage treatment via a pilot-scale air-lift multilevel circulation membrane bioreactor. Chemosphere 2019, 236, 124338. [CrossRef]

21. Lee, C.S.; Robinson, J.; Chong, M.F. A review on application of flocculants in wastewater treatment. Process. Saf. Environ. Prot. 2014, 92, 489-508. [CrossRef]

22. Sharma, S.K.; Sanghi, R. Advances in Water Treatment and Pollution Prevention; Springer Science \& Business Media: Berlin, Germany, 2012.

23. Ghaffour, N.; Missimer, T.M.; Amy, G.L. Technical review and evaluation of the economics of water desalination: Current and future challenges for better water supply sustainability. Desalination 2013, 309, 197-207. [CrossRef]

24. Del Pino, M.P.; Durham, B. Wastewater reuse through dual-membrane processes: Opportunities for sustainable water resources. Desalination 1999, 124, 271-277. [CrossRef]

25. European Comission. Ex-Post Evaluation of Directive 2000/59/EC on Port Reception Facilities for Ship-Generated Waste and Cargo Residues; Hart Publishing: Oxford, UK, 2015.

26. Lim, S.-R.; Park, D.; Park, J.M. Environmental and economic feasibility study of a total wastewater treatment network system. J. Environ. Manag. 2008, 88, 564-575. [CrossRef] [PubMed]

27. Hernández-Sancho, F.; Molinos-Senante, M.; Sala-Garrido, R. Economic valuation of environmental benefits from wastewater treatment processes: An empirical approach for Spain. Sci. Total. Environ. 2010, 408, 953-957. [CrossRef] [PubMed]

28. Bartels, C.R.; Wilf, M.; Andes, K.; Iong, J. Design considerations for wastewater treatment by reverse osmosis. Water Sci. Technol. 2005, 51, 473-482. [CrossRef] [PubMed]

29. Hernández-Sancho, F.; Lamizana-Diallo, B.; Mateo-Sagasta, J.; Qadir, M. Economic Valuation of Wastewater: The Cost of Action and the Cost of no Action; United Nations Environment Programme (UNEP): Nairobi, Kenya, 2015.

30. Molinos-Senante, M.; Hernández-Sancho, F.; Sala-Garrido, R. Economic feasibility study for wastewater treatment: A cost-benefit analysis. Sci. Total. Environ. 2010, 408, 4396-4402. [CrossRef] [PubMed]

31. Council of Aguas de Gran Canaria. Hydrological Plan of Gran Canaria; Canary Government: Las Palmas de Gran Canaria, Spain, 2010.

32. Lapuente, E. Full cost in desalination. A case study of the Segura River Basin. Desalination 2012, 300, 40-45. [CrossRef]

33. Uche-Soria, M.; Rodríguez-Monroy, C. Solutions to Marine Pollution in Canary Islands' ports: Alternatives and Optimization of Energy Management. Resources 2019, 8, 59. [CrossRef] 